\title{
Exchange Rate Policy and Export Promotion: Evidence from Uzbekistan
}

\author{
Elmurod Abdusattorovich Hoshimov
}

\begin{abstract}
This article is devoted to the analysis of the impact of exchange rate policy on export performance in terms of theory and practice. In addition, the article presents developed scientific proposals and practical recommendations aimed at enhancing the promoting role of exchange rate policy in improving export performance of the Republic of Uzbekistan.
\end{abstract}

Index Terms - exchange rate policy, devaluation, exchange rate, export, import, trade balance, intervention, capital flow, gold and foreign exchange reserves.

\section{INTRODUCTION}

During recent years Uzbekistan has been implementing a number of efficient measures aimed at further liberalization of the economy, in particular, liberalization of foreign exchange policy and its positive impact on the improvement of the entrepreneurial environment and enhancing export potential of economic entities.

In this regard, the Action Strategy for further development of the Republic of Uzbekistan approved by the Decree of the President of the Republic of Uzbekistan № 4947 on February 7, 2017 implies implementation of such top-target objectives within the third priority direction of developing and further liberalization of the digital economy as further improvement of monetary policy using instruments applied in international best practices, as well as the gradual introduction of modern market mechanisms in currency regulation, ensuring stability of the national currency.

In addition, in compliance with the Decree of the President of the Republic of Uzbekistan PD №5177 “On priority measures to liberalize monetary policy" as of September 2, 2017, the following issues have been outlined as prior areas: full implementation of the right of legal entities and individuals to freely buy and sell foreign exchange and to freely dispose of their funds at their own discretion; enhancing the role of market instruments in the use of foreign exchange resources, creating equal conditions for all economic entities in the foreign exchange market, enhancing promoting role of monetary policy in the development of exports in non-traditional sectors, strengthening regional and international economic cooperation; undertaking the measures required for the state support of the companies of the basic industries for their efficient operating in the new conditions of the foreign exchange policy.

As a result of the monetary policy liberalization, the exchange rate of the national currency against the USD has sharply increased. This has made a negative impact on the ability of businesses to service their foreign currency denominated loans. In order to mitigate these negative consequences, the foreign currency denominated loans extended to economic entities have been restructured.

Herewith a major focus is made on strengthening public confidence in the national currency, as well as preventing the problem of dollarization in the national economy.

\section{LITERATURE REVIEW}

Currently it is rather difficult to come to a single conclusion on assessing the exchange rate policy in terms of the interests of economic entities. In particular, economic agents engaged in international transactions challenge some risks associated with exchange rate fluctuations and therefore prefer stable exchange rates. On the other hand, manufacturers of export commodities prefer the elasticity of exchange rate, as it raises the chances of competing with foreign rivals [5].

Meanwhile, within the framework of "dollarization" of liabilities of companies or a high share of liabilities in foreign exchange and formation of assets mainly in the national currency, devaluation makes a negative impact on the balance sheet of companies, in particular, servicing debt becomes more expensive. As a result of devaluation, the value of net assets of companies decreases, the level of currency risk increases and access to credit reduces. In other words, the higher the level of dollarization and devaluation of liabilities is, the higher the negative impact on the balance sheet is made.

Having studied the impact of exchange rate fluctuations on the balance sheet and debt capital structure of companies, some economists think that the size and export orientation of the company are essential indicators in explaining the amount of losses occurred as a result of sharp exchange rate fluctuations [3].

However, there is a presence of a "positive competitiveness effect" which is characterized by the increase in the company's efficiency as a result of the exchange rate devaluation because devaluation causes lower prices for exported goods and services, and in reliance upon this fact makes a positive impact on the competitiveness of companies in international trade.

However, the positive (competitive) or negative impact (balance) caused by the devaluation depends on the level of elasticity of export and import prices in the country. In the case of imports of raw materials and capital goods (equipment and supplies), if imports are highly inelastic, there may be an 
adverse effect due to the rise in prices for raw materials and equipment, i.e. a decrease in the national GDP [2].

According to empirical researches carried out in 20022009 as a case-study of Croatian non-financial sector companies to assess the impact of exchange rate fluctuations on competitiveness and balance sheet, there has been observed a positive effect on the competitiveness of companies studied as the research object. However, since the competitive effect on the balance sheets of companies is lower than the loss from the depreciation of the exchange rate, i.e. the balance effect, the final result is negative [6].

Some empirical studies have also revealed that when imports of raw materials used for the production of exported goods are high, the impact of exchange rate fluctuations on exports is low, but the impact of exchange rates on exports of services is high [1]. However, in further researches V. Fang and $\mathrm{S}$. Miller reconsidered the exchange rate devaluation and export dependence as the evidence of Singapore, specifying that devaluation did not significantly affect export growth, but rather increased currency risk, so the Singapore monetary authority did not depreciate the exchange rate to support export growth, but decided to maintain sustainability in the country [4].

When Japanese economists studied the impact of exchange rate fluctuations on the efficiency of companies as a casestudy of approximately 360 thousand Japanese companies in 1990-2013, a number of correlations have been identified [7]. In particular:

a) as a result of the yen devaluation, sales of Japanese companies have significantly increased (30\% depreciation of the yen has caused the increase in sales of companies by $3.9 \%)$

b) the return on assets (ROA) of Japanese companies have also improved in terms of the yen devaluation (30\% depreciation of the yen has resulted in the increase in return on assets of companies by $0.3 \%$ ).

The research which examines the relationship between the real exchange rate and export competitiveness in East African countries illustrates that in the short-term prospect, the decline in the real effective exchange rate will promote the increase of the export of manufacturing companies with high labor intensity, low and medium demand for skills; on the contrary, the exchange rate devaluation makes a negative impact on the export of goods with high capacity of skills and technology [8].

The analysis of the current account balance and export efficiency in the new EU member states shows that the current account balance and export activity were more efficient in countries with floating exchange rates in the precrisis period. In addition, it was noted that the exchange rate policy could still be a useful measure in enhancing exports [9].

According to domestic scholars - economists A. Sh. Bekmurodov and N. Kh. Jumaev, the reliance on market mechanisms in the formation of the exchange rate of the UZS against hard currencies in the foreign exchange market is fully consistent with the liberalization policy in the foreign exchange sector. This requires the Central Bank to be able to make an impact on the supply and demand in the foreign exchange market in order to prevent sharp fluctuations in exchange rates and to provide sufficient foreign currency assets for this purpose [10].

\section{RESEARCh MEthodology}

In the research process, such methods as generalization, grouping, logical and comparative methods of analysis, abstract-logical thinking, comparative analysis, analysis of selected literature have been widely used.

\section{RESUlts AND DisCUSSION}

First of all, the following positive aspects of the monetary policy liberalization in our country should be mentioned:

- abolishing restrictions on capital flow will reduce an investor's expenditures;

- the investment climate in the country will improve;

- confidence of legal entities and individuals in the national currency - the UZS - will be strengthened, as well as the share of assets in the UZS will raise.

In our opinion, in analyzing the results of empirical research on the impact of exchange rate policy on the competitiveness of companies, it is required to pay a particular attention to the differences and peculiarities of developed and developing countries. Consequently, the trade deficit in developed countries is often explained by the export of high labor capacity in the production. Herewith, leading countries of the United States and the European Union have developed capital-intensive and high-tech sectors of the economy, which, in turn, take an enormous importance in attracting direct and portfolio investments.

In order to support exports and raise the competitiveness of the national companies, governments are trying to reduce the exchange rate of national currencies against foreign currencies because devaluation is considered as improving the business environment and creating conditions for business growth.

However, the trade deficit in insufficiently developed countries is justified by factors such as the low competitiveness of national goods, inability of local companies to compete adequately in domestic and international markets. Under such conditions, devaluation will not solve the problem of low competitiveness, nor will there be an increase in exports. As a result, devaluation can cause such negative consequences as a high inflation in the country, a decrease in the purchasing power of the national currency, high prices for imported equipment and facilities for modernization, as well as worsening conditions for servicing foreign currency loans.

As a result of the devaluation, export-oriented companies will have certain advantages, i.e. an exporting company will obtain additional devaluation income when converting its foreign exchange proceeds into the national currency.

Our analysis shows that in 2014-2019, the balance of goods and services of the Republic of Uzbekistan (trade balance) was in deficit in all cases, except for quarter 4 of 2015 (Fig. $1)$. 


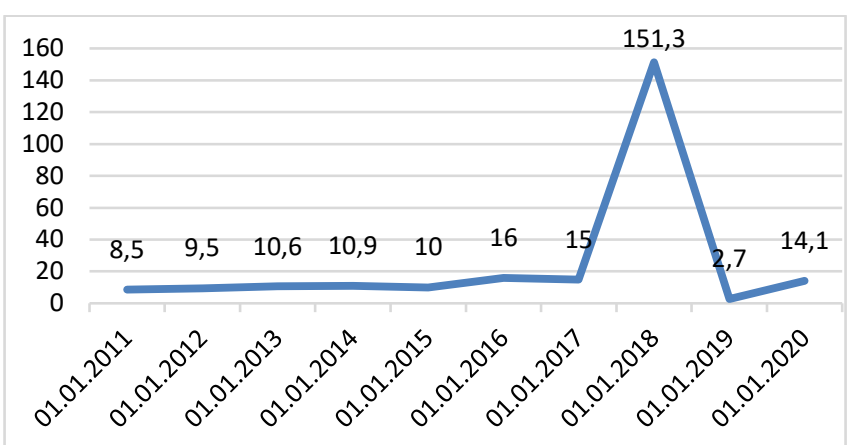

Fig. 2. Devaluation rate of the UZS against the USD, in \%*. * Developed by the author on the basis of the data of the Central Bank of the Republic of Uzbekistan.

However, during this period the exchange rate of the national currency - the UZS - against the USD was considerably devalued (Fig. 2). Theoretically, the devaluation should have made a positive impact on the foreign trade balance, in particular, to promote exports. In our opinion, this situation has emerged due to the trade regime of our country which because of various customs duties and other restrictions has not sufficiently encouraged a sharp decline in imports and an increase in exports.

Therefore, currently in terms of the monetary policy liberalization in our country, a particular focus is made not only on improving the practice of introducing market mechanisms of monetary policy, but to alternative methods of promoting the increase of export potential of economic entities as well. In particular, the practice of allocating export credits by commercial banks to increase the competitiveness of domestic producers in foreign markets is one of them. In particular, one of them is the practice of allocating export loans by commercial banks to enhance the competitiveness of domestic producers in foreign markets. Moreover, important measures are being undertaken to liberalize the trade regime, and reasonable approach to ensuring adequate conditions for our country's membership in the World Trade Organization will facilitate the increase of the monetary policy mechanisms efficiency in future.

Meanwhile, it is natural that exchange rate fluctuations in the foreign exchange market grow in exchange rates in line with the functioning of market mechanisms. This requires the intervention of the Central Bank to prevent sharp fluctuations in the national currency. In this process, the intervention of the Central Bank in the process of setting the exchange rate occurs by affecting supply and demand. Therefore, the potential of the Central Bank to efficiently implement the intervention is determined by the volume of its gold and foreign exchange reserves.

In recent years, there has been a growing trend in the volume of gold and foreign exchange reserves of the country (Fig.3). On the one hand, this indicates increasing capacity of the Central Bank to intervene in the foreign exchange market, and, on the other hand, is essential for the country's international solvency, liquidity and economic security. Herewith, as of July 1, 2020, the share of gold in the total official reserves constituted $61.6 \%$ and at the same time it seems that the current trend is positive in terms of rising gold prices. In our opinion, the development of gold-swap operations by the Central Bank to ensure liquidity in foreign exchange complies with the current foreign exchange reserves policy

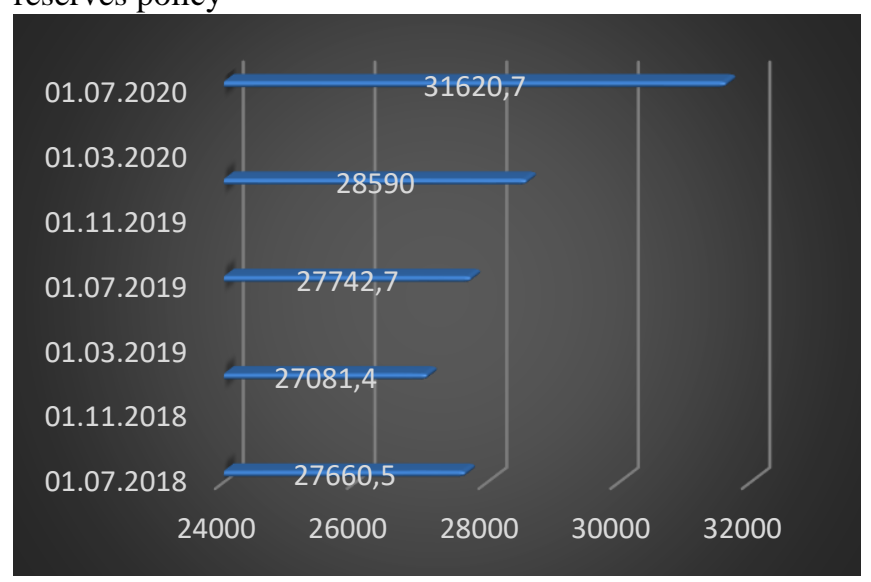

Fig. 3. Gold and currency reserves of the republic of Uzbekistan*.

*The author's calculations made on the basis of the data of the Central Bank of the Republic of Uzbekistan.

From our point of view, with the aim of further raising the efficiency of the monetary policy of the Central Bank of the Republic of Uzbekistan, it is required to develop instruments and markets for foreign exchange intervention. In particular, it is obligatory to use spot and REPO transactions as an intervention instrument in the interbank foreign exchange market of the country, and in the futures market - to make transactions with swap and forward agreements to influence liquidity and exchange rate expectations.

This is due to the fact that currency swap transactions in the derivatives market serve to cover the demand caused by hedging and speculative risks. For example, the Brazilian currency derivatives market is more liquid than the spot currency market, which in turn makes swap transactions the most widely used instrument in currency intervention.

\section{CONCLUSION AND PROPOSALS}

In general, in order to raise the promoting role of monetary policy in the development of exports in our country, in our opinion it is recommended to implement the following measures:

- with the aim of preventing the real exchange rate of the UZS against the currencies of Uzbekistan main trading partners, to apply an accelerated devaluation policy, if necessary;

- in order to ensure the stability of the exchange rate, to introduce currency swap agreements aimed at raising foreign exchange liquidity between the central banks of the main trading partner countries;

- with the aim of enhancing transparency of the exchange rate mechanism and limit the interference of the Central Bank in this process, to abandon the simple method of fixing the exchange rate in exchange trades;

- to develop currency swap and gold swap operations of the Central Bank in the foreign exchange market;

- in order to reduce the scale of dollarization in the national economy, to establish national gold market regime and to introduce market mechanisms of gold price;

- to develop the system of measures to prevent the "dollarization" of liabilities of commercial banks, including measures to hedge currency risk; 
- in order to stimulate the inflow of foreign capital into the national economy, to implement gradual liberalization of the system of capital flow regulation;

- in the new wording edition of the Law of the Republic of Uzbekistan "On currency regulation" it is necessary to specify in detail the cases when it is required to apply currency restrictions and set priorities not to harm the economic interests of residents and non-residents engaged in foreign exchange transactions;

- with the aim of promoting the sale of goods and services of local companies in foreign markets, to raise the volume of export loans extended by the commercial banks of the republic.

In conclusion it should be noted that it is inevitable that the final result of the impact of exchange rate fluctuations on the performance of companies, in particular, on export competitiveness, will be positive or negative. In particular, there is still uncertainty about the positive impact of devaluation on the competitiveness of companies through increase of their export potential. Therefore, in supporting exports by reducing the exchange rate of the UZS against foreign currencies, it is required to take into consideration factors such as the composition of the balance sheets of economic entities, in particular, expediency and quantity of foreign currency liabilities and assets, as well as import and export elasticity.

\section{REFERENCES}

[1] Tilak Abeysinghe, Tan Lin Yeok. (1998) Exchange rate appreciation and export competitiveness. The case of Singapore// Applied Economics, 1998, 30, p.51-55.

[2] Reif, T. (2001) The Real Side of Currency Crises. Columbia University Working Paper. 2001. 27 P.

[3] José M. Benavente, Christian A. Johnson. (2003) Debt Composition and Balance-Sheet Effects of Exchange Rate: A Firm level Analysis for Chile//Emerging Markets Review, Volume 4, Issue 4, December 2003, Pages 397-416

[4] WenShwo Fang, Stephen M. Miller. (2007) Exchange rate depreciation and exports: the case of Singapore revisited// Applied Economics, Volume 39, 2007 - Issue 3, Pages 273-277.

[5] Frieden, Jeffry; Leblang, David; Valev, Neven. (2010) The political economy of exchange rate regimes in transition economies // Review of International Organizations, Mar 2010. Pages 21-35.

[6] Tkalec Marina, Verbič Miroslav. (2013) A New Look Into the Prevalence of Balance Sheet or Competitiveness Effect of Exchange Rate Depreciation in a Highly Euroised Economy. Post- Communis Economies, 25(2013), 2, pp. 225-240.

[7] Takashi Hanagaki and Masahiro Hori. (2015) The Exchange Rate and the Performance of Japanese Firms: A Preliminary Analysis Using Firm-level Panel Data// Economic and Social Research Institute, $\begin{array}{lllll}\text { Cabinet Office, } & \text { JAPAN, } 2015 . & 47 & \text { P }\end{array}$ (http://www.esri.go.jp/jp/workshop/150731/Session4_hori_b.pdf)

[8] Fetene Bogale Hunegnaw. (2017) Real Exchange Rate and Manufacturing Export Competitiveness in Eastern Africa// Journal of Economic Integration, Vol.32 No.4, December 2017, 891 912 http://dx.doi.org/10.11130/jei.2017.32.4.891

[9] Željko Bogdan, Boris Cota, Nataša Erjavec. (2017) Current Account Balance and Export Performances: Evidence Based on New EU Countries// Zagreb International Review of Economics \& Business, Vol. 20, No. 2, 2017. - pp. 33-48.

[10] Bekmurodov A.Sh., Jumaev N. Kh. (2019) Conceptual aspects of balance of payments regulation in terms of the monetary policy liberalization//electronic journal “Uzbridge”. № I. 2019. P.3-14. 